\title{
Effects of long-term fertilizer practice on fungal and actinobacterial cellulolytic communities with different humified particle-size fractions in a double-cropping paddy field
}

Haiming Tang ( $\nabla$ tanghaiming66@163.com )

Soil and Fertilizer Institute of Hunan Province

Chao Li

Soil and Fertilizer Institute of Hunan Province

Yilan Xu

Hunan Biological and Electromechanical Polytechnic

\section{Kaikai Cheng}

Soil and Fertilizer Institute of Hunan Province

Lihong Shi

Soil and Fertilizer Institute of Hunan Province

\section{Li Wen}

Soil and Fertilizer Institute of Hunan Province

Weiyan Li

Soil and Fertilizer Institute of Hunan Province

Xiaoping Xiao

Soil and Fertilizer Institute of Hunan Province

\section{Research Article}

Keywords: rice, fertilizer treatment, paddy field, humic, cellulolytic, particle-size fraction

Posted Date: February 15th, 2021

DOI: https://doi.org/10.21203/rs.3.rs-227248/v1

License: (c) (i) This work is licensed under a Creative Commons Attribution 4.0 International License. Read Full License 


\section{Abstract}

Cellulose plays an important role in maintaining or improving soil carbon (C) cycling and soil fertility. And there has closely relationship between functional cellulose genes (cbhl and $\mathrm{GH} 48$ ) with characterize of soil organic matter chemical components (fulvic acid and humic acid) and soil physical fractions. However, there is still limited information on how functional cellulose degradation responded to long-term fertilizer management and their relative importance for $\mathrm{C}$ sequestration under double-cropping rice paddy field in southern China. Therefore, the effects of 34year long-term fertilizer regime on community abundance of $\mathrm{cbhl}$ and $\mathrm{GH} 48$ in five soil particle-size fractions were investigated by using polarization magic angle spinning 13C nuclear magnetic resonance spectroscopy. The field experiment consisted of four different fertilizer treatments: chemical fertilizer alone (MF), rice straw residue and chemical fertilizer (RF), 30\% organic manure and 70\% chemical fertilizer (OM), and without fertilizer input as control (CK). The results showed that distribution of soil humus and cellulolytic microbial community abundance were significantly increased under long-term application of crop residue and organic manure condition. And the FA, HA and HM C contents in $>2000 \mu \mathrm{m}$ and 2000-50 $\mu \mathrm{m}$ fractions with MF, RF and OM treatments were significantly higher than that of CK treatment. Meanwhile, the alkyl C and Oalkyl C groups of FA in $>2000 \mu \mathrm{m}$ and 2000-50 $\mu \mathrm{m}$ fractions were higher than that of the other fractions, the order of relative abundance of different $\mathrm{C}$ groups of $\mathrm{HA}$ in different particlesize fractions were following alkyl C>0-alkyl C>aromatic C>carboxylic $\mathrm{C}$ with $\mathrm{MF}, \mathrm{RF}, \mathrm{OM}$ and $\mathrm{CK}$ treatments. The results indicated that abundance of cbhl and GH48 genes in different particle-size fractions were significantly increased with $\mathrm{RF}$ and $\mathrm{OM}$ treatments, compared with CK treatment. There were significantly positive correlation between chemical composition of FA and $\mathrm{HA}$ with cbhl and $\mathrm{GH} 48$ abundances. As a result, the cellulolytic gene abundance were significantly increased under combined application of crop residue and organic manure with chemical fertilizer condition.

\section{Introduction}

Soil organic matter (SOM) plays a vital role in maintaining soil quality and improving agricultural productivity ${ }^{1}$. Furthermore, agricultural soil have account for a large proportion in global greenhouse gas emission, which is to mitigate global climate warming through increasing carbon (C) sequestration in agricultural soil, decreasing carbon dioxide $\left(\mathrm{CO}_{2}\right)$ content in the atmospheric ${ }^{2}$. A higher SOM content can improve soil quality and represent a substantial contribution to reduction of $\mathrm{C}$ emission via $\mathrm{C}$ sequestration ${ }^{3}$. Therefore, it is beneficial to maintain soil quality and improvement of soil productivity by increasing SOM content.

SOM content and quality were closely related with different particle-size fractionation of soil. Particle-size fractionation, which allows for the separation of SOM pool with changing degrees of microbial alteration and mineral association, might help elucidate microbially-mediated soil C cycling characteristic ${ }^{4-5}$. In the previous studies, these results indicated that SOM was mostly derived from the decomposition of animal and plant litter, soil humus component were mainly affected by environmental change, such as different soil type ${ }^{6}$, crop system ${ }^{7}$, fertilizer regime 8 and so on. Humus is mainly component of SOM, and humus are mainly including of fulvic acid (FA), humic acid (HA) and humin (HM), which are the most ubiquitous non-living natural organic compounds in the soil ${ }^{9}$. However, there is still limited information about how the soil particle-size fractions respond to chemical and spectroscopic characteristic of soil humus under long-term fertilization condition.

Soil humification is mainly a microbially-mediated in process of soil $\mathrm{C}$ cycling, and cellulose decomposition is a critical process of soil $\mathrm{C}$ transformation as cellulose is the most abundant polysaccharide in plant litter that enters soil ${ }^{10}$. In the soil enzyme with $\mathrm{C}$ cycling aspect, it is well known that decomposition of cellulose is mainly completed through the synergistic activity of three major groups of enzymes, such as endoglucanases, cellobiohydrolases and $\beta$-glucosidases 
11. During the rate-limiting step of cellulose decomposition, cellulolytic enzyme were mainly encoded by the fungal glycoside hydrolase family 7 cellobiohydrolase I gene (cbhl) and bacterial glycoside hydrolase family $48(G H 48)^{12}$. In recent years, some results indicated that fungal $c b h /$ in Ascomycota and Basidiomycota can representative group of cellulolytic fungi ${ }^{13-14}$, and the abundance and diversity of $\mathrm{GH} 48$ gene detected from actinobacteria can representative ecological role in soil $\mathrm{C}$ cycling ${ }^{15}$ Therefore, it was benefit for explanation of $\mathrm{C}$ transformation mechanism to investigate of the key functional gene corresponding to specific soil microorganism involved in cellulose decomposition under long-term fertilization condition ${ }^{16}$.

Rice is one of the main crops in Asia, and double-cropping rice system (early rice and late rice) is the main land use in southern of China ${ }^{18}$. It is benefit practice for maintaining or improving the paddy field quality and fertility by combined application of organic fertilizer with inorganic fertilizer ${ }^{2,18}$. And the different fertilizer management may profound effects on soil physical and chemical characteristic such as $\mathrm{pH}$, soil bulk density, SOC content ${ }^{18}$, which in return affect functional humus fractions and $\mathrm{C}$ sequestration. We hypothesized that: (i) chemical and structural characteristic of soil humus would be changed under long-term application of different fertilization condition; (ii) fungal and actinobacterial cellulolytic community abundance would be influenced by fertilization, particle-size fraction and their interaction effects, and (iii) correlation between cellulolytic microbial abundance with soil humus were also changed under application of different fertilization condition. Therefore, the 34-year long-term field experiment with different fertilizer treatments were conducted in a double-cropping rice system in the southern of China. Hence, the objective of this study was: (1) to illustrate the chemical and structural characteristic of soil humus (FA, HA and HM) with different fertilizer practice in a double-cropping rice system; (2) to investigate the abundance of $c b h /$ and $G H 48$ genes in five particle-size fractions ( $>2000 \mu \mathrm{m}, 2000-200 \mu \mathrm{m}, 200-50 \mu \mathrm{m}, 50-2 \mu \mathrm{m}$ and 2-0.1 $\mu \mathrm{m})$ in paddy field under long-term fertilization condition.

\section{Materials And Methods}

mol L-1 $\mathrm{NaOH}$ in $0.1 \mathrm{~mol} \mathrm{~L}^{-1}$ sodium pyrophosphate under a $\mathrm{N}_{2}$ atmosphere and it were repeated several times until colorless supernatants were obtained. The suspensions were centrifuged at $5000 \times \mathrm{g}$ for $15 \mathrm{~min}$ and the pooled alkali extract was acidified to $\mathrm{pH} 2.0$ with $\mathrm{H}_{2} \mathrm{SO}_{4}$, and kept for $24 \mathrm{~h}$ at room temperature. The soluble fulvic acid (FA) was separated from coagulation (humic acid (HA) fraction) by centrifugation ${ }^{9}$. The residue, which was the precipitate in the centrifuge tube, was collected to provide humin (HM). Total C content of FA and HA were tested by MultiB/C3100TOC/TN and those of HM were measured by using a vario MACRO cube element analyzer (Elementar Analysensysteme $\mathrm{GmbH}$, Hanau, Germany). The soil C content of humus (FA, HA and HM) of all the soil samples were investigated according to the method described as by Jindog et al. ${ }^{8}$.

\subsubsection{CPMAS solid-state ${ }^{13} \mathrm{C}$ NMR spectroscopy}

In the present study, chemical composition of purified FA and HA fractions of soil samples with MF, RF, OM and CK treatments were via CPMAS solid-state ${ }^{13} \mathrm{C}$ NMR spectroscopy and expressed as the relative abundance of the major $\mathrm{C}$ types. The solid-state ${ }^{13} \mathrm{C}$ NMR spectra were measured on a Bruker Avance III 400 NMR spectrometer (Germany) conducting at a spinning speed of $5 \mathrm{kHz}$ and a contact time of $1 \mathrm{~ms}$, with a ${ }^{1} \mathrm{H} 90{ }^{\circ} \mathrm{C}$ pulse length of $4 \mu$ and a recycle delay of $0.8 \mathrm{~s}$. The chemical shift regions 0-45, 45-95, 95-165 and 165-200 ppm were referred to alkyl C, o-alkyl C, aromatic $C$ and carboxylic $C$, respectively ${ }^{21}$. The areas of the spectral regions were measured though the integration routine of the spectrometer and expressed as percentage of the sum of all spectral areas respectively ${ }^{22}$. The degree of aromaticity (ARO\%) and aliphaticity (AL\%) of the FA and HA were calculated according to the equations as below: 


$$
\operatorname{ARO}(\%)=\frac{\text { Aromatic } C(95-165 \mathrm{ppm})}{\mathrm{C} \text { signal }(0-165 \mathrm{ppm})}
$$

$$
\mathrm{AL}(\%)=\frac{\text { Aliphatic } C(0-95 \mathrm{ppm})}{\mathrm{C} \text { signal }(0-165 \mathrm{ppm})}
$$

The alkyl C/o-alkyl $\mathrm{C}$ ratio were calculated and regarded as an indicator of the degree of organic matter decomposition 23

2.4.3 DNA extraction and quantitative polymerase chain reaction (qPCR) assay

Soil DNA were extracted from $0.5 \mathrm{~g}$ fresh soil by using the FastDNA ${ }^{\circledR}$ SPIN Kit (MP Biomedicals, Illkirch, France) and a Fast Prep-24 Homogenization System (MP Biomedicals, Irvine, CA) according to the manufacturer's instructions. Successful DNA extraction were characterized by electrophoresis on $1 \%$ (wt/vol) agarose gels. The quantity and quality of DNA were checked by using Nanodrop spectrophotometer (Nanodrop, PeqLab, Germany).

Genes encoding fungal glycoside hydrolase family 7 cellobiohydrolase I gene ( $c b h)$ and bacterial glycoside hydrolase family 48 (GH48) were selected as biomarkers of cellulolytic fungi and actinobacteria, respectively. All qPCR assays were carried out in an iCycler system (BioRad, USA) by using SYBR Green I chemistry and the data were analyzed by using Bio-Rad iQ5 v2.0, quantitative PCR were investigated according to the method described as by Fan et al. ${ }^{24}$.

\subsection{Statistical analysis}

The statistical analyses of this manuscript were conducted by using SAS 9.3 software package ${ }^{25}$. The data of different fertilizer treatments and particle-size fractions in this manuscript were compared by using Fisher's significant difference at the $p<0.05$ probability level. Pearson's correlation analyses were performed to assess the linear correlation among soil properties, enzyme activity, $\mathrm{C}$ groups of FA and HA with $c b h /$ and $G H 48$ gene abundance. The results were expressed as means and standard errors.

\section{Results}

\subsection{Soil humus composition}

In different particle-size fractionation, the highest $\mathrm{C}$ content of humus (FA, HA and HM) were found in 200-50 $\mu \mathrm{m}$ fraction, and the lower content were found in 50-0.1 $\mu \mathrm{m}$ fraction (Fig. $1 \mathrm{a}-\mathrm{C}$ ). Compared with MF treatment, the FA and HM C content in 2000-200 $\mu \mathrm{m}$ and 50-0.1 $\mu \mathrm{m}$ fractions were significantly $(p<0.05)$ improved with organic material application (RF and OM) treatments (Fig. 1 a and c), whereas the improvement of HA C content in 200-50 $\mu \mathrm{m}$ fraction was not significantly difference (Fig. 1 b). The results indicated that the FA, HA and HM C content in $>2000 \mu \mathrm{m}$ and 2000-50 $\mu \mathrm{m}$ fractions with MF, RF and OM treatments were significantly $(p<0.05)$ higher than that of CK treatment. Particle-size fractions and fertilizer treatments were significantly $(p<0.05)$ influence on the distribution of humus components (FA, HA and HM), but their interaction effect on HA C content was not significantly difference $(p>0.05)$ (Table 1).

Table 1 Two-way ANOVA analysis of soil humus, $c b h l$, and GH48 gene abundance in the five soil particle-size fractions and fertilizer treatments 


\begin{tabular}{|lllllll|}
\hline & \multicolumn{2}{l}{ Particle-size fractions } & \multicolumn{2}{l}{ Fertilizer } & \multicolumn{2}{l|}{ Particle-size fractions $\times$ Fertilizer } \\
\cline { 2 - 7 } & $F$ & $P$ & $F$ & $P$ & $F$ & $P$ \\
\hline FA & 86.52 & $<0.001$ & 84.26 & $<0.001$ & 3.56 & $<0.001$ \\
HA & 91.67 & $<0.001$ & 61.58 & $<0.001$ & 1.62 & 0.135 \\
HM & 80.47 & $<0.001$ & 70.24 & $<0.001$ & 3.27 & $<0.001$ \\
\hline Rice season & & & & & & \\
cbh/abundance & 84.26 & $<0.001$ & 72.04 & $<0.001$ & 4.63 & $<0.001$ \\
\hline GH48 abundance & 12.35 & 0.146 & 14.17 & 0.185 & 0.86 & 0.362 \\
\hline
\end{tabular}

Note: FA: fulvic acid, HA: humic acid, HM: humin.

The data in bold indicated the parameter was not significantly affected by soil particle-size fractions, fertilizer treatments or their interaction $(P<0.05)$.

\subsection{CPMAS solid-state ${ }^{13} \mathrm{C}$ NMR spectroscopy}

The effects of different fertilizer treatments on relative abundance of different $\mathrm{C}$ groups of FA in particle-size fractions were showed in Table 2. The results showed that alkyl C and oalkyl C groups in $>2000 \mu \mathrm{m}$ and 2000-50 $\mu \mathrm{m}$ fractions were higher than that of the other fractions (Table 2). However, carboxylic $C$ was most abundant in 50-2 $\mu$ m and 2-0.1 $\mu \mathrm{m}$ fractions, which resulted in an ultimately higher ARO\% of the FA in these particle-size fractions. Aliphatic $\mathrm{C}$ was most abundant in $>2000 \mu \mathrm{m}$ and 200-50 $\mu \mathrm{m}$ fractions, which resulted in an ultimately higher AL\% of the FA in these particle-size fractions. There was no obvious significantly $(p>0.05)$ difference in the proportion of aromatic $C$ group among the five fractions and fertilizer treatments. The Alkyl/o-alkyl of FA in 200-50 $\mu \mathrm{m}$ and 50-2 $\mu \mathrm{m}$ fractions were lower than $(p<0.05)$ that of the other fractions.

The results indicated that order of relative abundance of different $\mathrm{C}$ groups of $\mathrm{HA}$ in particle-size fractions were following alkyl $\mathrm{C}>0$-alkyl $\mathrm{C}>$ aromatic $\mathrm{C}$, and the lowest relative abundance of $\mathrm{C}$ groups of $\mathrm{HA}$ in particle-size fractions was carboxylic $C$ (Table 2). Meanwhile, this result showed that there has higher ARO\% and lower AL\% of HA in 200-50 $\mu \mathrm{m}$ fraction. And the alkyl/o-alkyl of HA was lowest in 200-50 $\mu \mathrm{m}$ fraction and higher in 50-2 $\mu \mathrm{m}$ and 2-0.1 $\mu \mathrm{m}$ fractions with RF, MF and OM treatments.

Table 2 Contribution of the different humus $\mathrm{C}$ types, aromaticity (ARO\%), alphaticity (AL\%) and alkyl/o-alkyl ratio determined by CPMAS ${ }^{13} \mathrm{C}$ NMR of FA and HA in soil particle-size fractions under different fertilizer treatments 


\begin{tabular}{|c|c|c|c|c|c|c|c|c|}
\hline \multirow[t]{2}{*}{$\begin{array}{l}\text { Particle-size } \\
\text { fractions }\end{array}$} & \multirow[t]{2}{*}{ Treatments } & $\begin{array}{l}0-45 \\
\text { ppm }\end{array}$ & $\begin{array}{l}45-95 \\
\mathrm{ppm}\end{array}$ & $\begin{array}{l}\text { 95-165 } \\
\text { ppm }\end{array}$ & $\begin{array}{l}165-200 \\
\text { ppm }\end{array}$ & \multirow[t]{2}{*}{ ARO $\%$} & \multirow[t]{2}{*}{$A L \%$} & \multirow[t]{2}{*}{$\begin{array}{l}\text { Alkyl/o- } \\
\text { alkyl }\end{array}$} \\
\hline & & Alkyl C & O-alkyl C & $\begin{array}{l}\text { Aromatic } \\
\mathrm{C}\end{array}$ & $\begin{array}{l}\text { Carboxylic } \\
\text { C }\end{array}$ & & & \\
\hline \multicolumn{9}{|l|}{ FA } \\
\hline \multirow[t]{4}{*}{$\nabla 2000 \mu \mathrm{m}$} & MF & 26.7 & 30.7 & 22.6 & 17.5 & 28.25 & 71.75 & 0.87 \\
\hline & RF & 30.6 & 26.5 & 20.9 & 18.3 & 26.79 & 73.21 & 1.15 \\
\hline & $\mathrm{OM}$ & 32.5 & 28.4 & 20.4 & 18.7 & 25.09 & 74.91 & 1.14 \\
\hline & CK & 38.6 & 18.5 & 21.5 & 16.3 & 27.35 & 72.65 & 2.09 \\
\hline \multirow[t]{4}{*}{$2000-200 \mu \mathrm{m}$} & MF & 18.5 & 14.2 & 23.1 & 40.5 & 41.40 & 58.60 & 1.30 \\
\hline & RF & 20.1 & 19.4 & 22.1 & 36.7 & 35.88 & 64.12 & 1.04 \\
\hline & $\mathrm{OM}$ & 20.6 & 20.3 & 22.6 & 35.4 & 35.59 & 64.41 & 1.01 \\
\hline & CK & 21.8 & 16.7 & 20.7 & 38.7 & 34.97 & 65.03 & 1.31 \\
\hline \multirow[t]{4}{*}{$200-50 \mu \mathrm{m}$} & MF & 28.6 & 28.5 & 25.3 & 18.7 & 30.70 & 69.30 & 1.00 \\
\hline & RF & 29.2 & 31.7 & 24.3 & 17.6 & 28.52 & 71.48 & 0.92 \\
\hline & $\mathrm{OM}$ & 29.6 & 32.4 & 24.7 & 17.1 & 28.49 & 71.51 & 0.91 \\
\hline & CK & 27.4 & 30.3 & 23.5 & 18.2 & 28.94 & 71.06 & 0.90 \\
\hline \multirow[t]{4}{*}{$50-2 \mu \mathrm{m}$} & MF & 14.5 & 21.6 & 26.4 & 42.3 & 42.24 & 57.76 & 0.67 \\
\hline & RF & 14.1 & 20.7 & 25.1 & 45.7 & 41.90 & 58.10 & 0.68 \\
\hline & $\mathrm{OM}$ & 13.6 & 21.2 & 25.6 & 46.8 & 42.38 & 57.62 & 0.64 \\
\hline & CK & 15.2 & 20.1 & 18.9 & 51.6 & 34.87 & 65.13 & 0.76 \\
\hline \multirow[t]{4}{*}{$2-0.1 \mu \mathrm{m}$} & MF & 26.5 & 12.1 & 31.6 & 40.7 & 45.01 & 54.99 & 2.19 \\
\hline & $\mathrm{RF}$ & 27.1 & 16.6 & 29.4 & 38.2 & 40.22 & 59.78 & 1.63 \\
\hline & $\mathrm{OM}$ & 27.8 & 17.5 & 31.1 & 36.5 & 40.71 & 59.29 & 1.59 \\
\hline & CK & 24.7 & 14.4 & 28.7 & 42.6 & 42.33 & 57.67 & 1.72 \\
\hline \multicolumn{9}{|l|}{ HA } \\
\hline \multirow[t]{4}{*}{$\varangle 2000 \mu \mathrm{m}$} & MF & 46.7 & 33.4 & 25.4 & 12.7 & 24.08 & 75.92 & 1.40 \\
\hline & RF & 44.5 & 31.8 & 27.6 & 13.1 & 26.56 & 73.44 & 1.40 \\
\hline & $\mathrm{OM}$ & 41.8 & 31.1 & 28.7 & 13.6 & 28.25 & 71.75 & 1.34 \\
\hline & CK & 50.7 & 32.5 & 23.6 & 10.5 & 22.10 & 77.90 & 1.56 \\
\hline \multirow[t]{4}{*}{$2000-200 \mu \mathrm{m}$} & MF & 34.7 & 29.3 & 25.3 & 13.1 & 28.33 & 71.67 & 1.18 \\
\hline & RF & 32.2 & 30.6 & 28.0 & 13.6 & 30.84 & 69.16 & 1.05 \\
\hline & $\mathrm{OM}$ & 31.5 & 31.2 & 28.6 & 14.2 & 31.33 & 68.67 & 1.01 \\
\hline & CK & 33.6 & 31.5 & 27.2 & 11.4 & 29.47 & 70.53 & 1.07 \\
\hline
\end{tabular}




\begin{tabular}{|c|c|c|c|c|c|c|c|c|}
\hline \multirow[t]{4}{*}{$200-50 \mu \mathrm{m}$} & MF & 23.5 & 28.7 & 33.7 & 15.6 & 39.23 & 60.77 & 0.82 \\
\hline & $\mathrm{RF}$ & 25.2 & 29.6 & 32.8 & 14.6 & 37.44 & 62.56 & 0.85 \\
\hline & $\mathrm{OM}$ & 25.8 & 30.2 & 31.7 & 15.1 & 36.15 & 63.85 & 0.85 \\
\hline & CK & 24.6 & 27.6 & 34.5 & 13.7 & 39.79 & 60.21 & 0.89 \\
\hline \multirow[t]{4}{*}{$50-2 \mu \mathrm{m}$} & MF & 40.3 & 30.5 & 23.7 & 14.5 & 25.08 & 74.92 & 1.32 \\
\hline & $\mathrm{RF}$ & 42.6 & 28.8 & 25.1 & 13.1 & 26.01 & 73.99 & 1.48 \\
\hline & $\mathrm{OM}$ & 43.5 & 29.6 & 25.6 & 13.8 & 25.94 & 74.06 & 1.47 \\
\hline & CK & 45.8 & 27.6 & 21.6 & 10.5 & 22.74 & 77.26 & 1.66 \\
\hline \multirow[t]{4}{*}{ 2-0.1 $\mu \mathrm{m}$} & MF & 40.2 & 30.2 & 26.1 & 12.7 & 27.05 & 72.95 & 1.33 \\
\hline & $\mathrm{RF}$ & 42.7 & 31.2 & 23.5 & 11.6 & 24.13 & 75.87 & 1.37 \\
\hline & $\mathrm{OM}$ & 43.5 & 32.5 & 24.3 & 10.1 & 24.23 & 75.77 & 1.34 \\
\hline & CK & 41.6 & 28.8 & 21.7 & 14.9 & 23.56 & 76.44 & 1.44 \\
\hline
\end{tabular}

MF: chemical fertilizer alone; RF: rice straw residue and chemical fertilizer; OM: $30 \%$ organic manure and $70 \%$ chemical fertilizer; CK: without fertilizer input as control.

\section{$3.3 \mathrm{cbhl}$ and $\mathrm{GH} 48$ gene abundance}

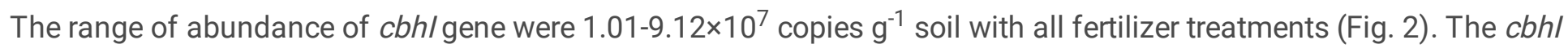
abundance were significantly impacted by particle-size fractions and fertilizer treatments individually and interactively $(P<0.001 ;$ Table 1). Although the lowest $c b h /$ abundance were observed in 2-0.1 $\mu \mathrm{m}$ fraction, the $c b h /$ abundance in 2000-2 $\mu \mathrm{m}$ fraction were relatively higher $(p<0.05)$ than those in the other fractions. The abundance of $c b h /$ gene in different particle-size fractions with MF, RF and OM treatments were higher than that of CK treatment. Furthermore, the abundance of $c b h /$ gene in different particle-size fractions with RF and OM treatments were significantly higher $(p<0.05)$ than that of MF and CK treatments.

The range of abundance of $\mathrm{GH} 48$ gene were $1.35-13.52 \times 10^{6} \mathrm{copies}^{-1}$ soil with all fertilizer treatments, which were about ten times lower than that of abundance of $c b h /$ gene (Fig. 3). Both particle-size fractions and fertilizer treatment individually affect $\mathrm{GH} 48$ abundance but the interactively effect was not significantly (Table 1). The results showed that GH48 abundance in $200-50 \mu \mathrm{m}$ fraction were relatively higher $(p<0.05)$ than those in the other fractions. And the abundance of $\mathrm{GH} 48$ gene in different particle-size fractions with MF, RF and OM treatments were higher than that of CK treatment. Furthermore, the abundance of $G H 48$ gene in $>2000 \mu \mathrm{m}, 2000-200 \mu \mathrm{m}$ and 200-50 $\mu \mathrm{m}$ fractions with RF and $\mathrm{OM}$ treatments were significantly higher $(p<0.05)$ than that of MF and CK treatments. However, there were no significantly differences $(p>0.05)$ in the abundance of $G H 48$ gene in 20-5 $\mu \mathrm{m}$ fraction with MF, RF, OM and CK treatments.

\subsection{Correlation analysis}

There has significantly positive correlation between $\beta$-glucosidase and $\beta$-cellobiohydrolase activities with $c b h /$ and GH48 abundance $(p<0.01)$ (Table 3). Meanwhile, the abundance of $G H 48$ were significantly correlated with soil properties (SOC, total $\mathrm{N}$, and $\mathrm{C} / \mathrm{N}$ ) and soil humus components (FA, HA and $\mathrm{HM})(p<0.01)$. And the abundance of $c b h l$ were significantly correlated with soil $\mathrm{C} / \mathrm{N}, \mathrm{FA}$ and $\mathrm{HA}(p<0.01)$ (Table 3 ). 
Meanwhile, the results indicated that there was no relationship between alkyl $\mathrm{C}$ and aromatic $\mathrm{C}$ of $\mathrm{FA}$ with $c b h /$ and GH48 abundance ( $p>0.05)$ (Table 4). Interestingly, C groups like o-alkyl C $(p<0.01)$ and AL\% of FA $(p<0.05)$ were positively correlated with $\mathrm{cbh} /$ and $\mathrm{GH} 48$ abundance, however, ARO\% were negatively correlated with $\mathrm{cbh}$ and $\mathrm{GH} 48$ abundance $(p<0.05)$. The results showed that both $c b h /$ and $G H 48$ abundance were negatively correlated with alkyl C, AL\%, alkyl/o-alkyl of HA ( $p<0.05)$, but $c b h /$ and $G H 48$ abundance were positively correlated with ARO\% ( $p<0.05)($ Table 4).

Table 3 Correlation coefficients between soil nutrient, humic substances, enzyme activity and cbh/and $\mathrm{GH} 48$ abundance in different particle-size fractions under different fertilizer treatments

\begin{tabular}{|llllllllll|}
\hline & SOC & $\begin{array}{l}\text { Total } \\
\text { N }\end{array}$ & C/N & FA & HA & HM & $\begin{array}{l}\beta- \\
\text { glucosidase }\end{array}$ & $\begin{array}{l}\beta- \\
\text { cellobiohydrolase }\end{array}$ & $G H 48$ \\
\hline$c b h l$ & $0.625^{*}$ & ns & $0.803^{* *}$ & $0.785^{*}$ & $0.758^{*}$ & 0.547 & $0.782^{*}$ & $0.796^{*}$ & $0.807^{* \star}$ \\
\hline GH48 & $0.874^{* *}$ & $0.506^{*}$ & $0.612^{*}$ & $0.891^{* *}$ & $0.816^{* *}$ & $0.806^{* *}$ & $0.893^{* *}$ & $0.851^{* *}$ & \\
\hline
\end{tabular}

Note: SOC: soil organic carbon; FA: fulvic acid, HA: humic acid, HM: humin.

${ }^{*} p<0.05 ;{ }^{* *} p<0.01 . \mathrm{ns}$ indicated no significant relationship were detected.

Table 4 Correlation coefficients between chemical composition of C groups of FA and HA with cbh/and GH48 abundance in different particle-size fractions under different fertilizer treatments

\begin{tabular}{|llllllll|}
\hline & Alkyl C & O-alkyl C & Aromatic C & Carboxylic C & ARO $\%$ & AL\% & Alkyl/O-alkyl \\
FA & & & & & & & \\
cbhl & ns & $0.702^{* *}$ & ns & ns & $-0.527^{*}$ & $0.548^{*}$ & $-0.586^{*}$ \\
GH48 & ns & $0.736^{* *}$ & ns & $-0.514^{*}$ & $-0.536^{*}$ & $0.573^{*}$ & ns \\
HA & & & & & & & \\
cbhl & $-0.735^{* *}$ & ns & $0.568^{*}$ & $0.572^{*}$ & $0.608^{*}$ & $-0.607^{*}$ & $-0.705^{* *}$ \\
GH48 & $-0.612^{*}$ & ns & $0.545^{*}$ & ns & $0.614^{*}$ & $-0.593^{*}$ & $-0.613^{*}$ \\
\hline
\end{tabular}

Note: ${ }^{*} p<0.05 ;{ }^{* *} p<0.01$. ns indicated no significant relationship were detected.

\section{Discussion}

Soil organic matter is a complex, heterogeneous mixture of various material with a continuum of decomposition and stabilization in the soil ${ }^{26}$. Humus were represent a large portion of natural organic matter distributed in soil, sediment and water ${ }^{27}$. In the present study, humus were occupied mainly component of SOC, which were consistent with previous reported ${ }^{28}$. This results showed that higher alkyl carbon (C) proportion and lower carboxylic $\mathrm{C}$ proportion of HA than that of FA in all soil fractions (Table 2) for that HA was higher in molecular weight and contain less oxygencontaining functional groups when compared with FA ${ }^{29}$. In the previous study, the results indicated that ARO\% of HA was two or three times higher than that of $\mathrm{FA}^{30}$, in the present study, the relatively higher ARO\% of $\mathrm{HA}$ in $200-50 \mu \mathrm{m}$ 
fraction which probably due to that chemical structure of different humus component might depend on the heterogeneous environment that formed in different particle-size fractions.

In the present study, the results showed that carboxylic C of FA in 50-2 $\mu \mathrm{m}$ and 2-0.1 $\mu \mathrm{m}$ fractions were higher than that of the other fractions (Table 2). Some results indicated the alkyl/o-alkyl of soil FA were usually proposed as a sensitive index of SOM decomposition ${ }^{31-32}$, and the alkyl/o-alkyl of soil FA were lower in 200-50 $\mu \mathrm{m}$ fraction but higher in 50-2 $\mu \mathrm{m}$ and 2-0.1 $\mu \mathrm{m}$ fractions in this study. Meanwhile, this results indicated that dominant $\mathrm{C}$ group of HA in 200-50 $\mu \mathrm{m}$ fraction were aromatic $\mathrm{C}$ and it were different from the other soil fractions that were dominated by alkyl $\mathrm{C}$, thus resulting in the highest ARO\% and lowest AL\% in 200-50 $\mu \mathrm{m}$ fraction. Together with the lowest alkyl/o-alkyl of HA, these results further suggested that relatively lower humification degree in 200-50 $\mu \mathrm{m}$ fraction than that of the other fractions ${ }^{33}$. On the contrary, alkyl/o-alkyl of HA in 50-2 $\mu \mathrm{m}$ and 2-0.1 $\mu \mathrm{m}$ fractions were higher than that of other soil fractions suggested that there were more stable organic matter and a possible accumulation of recalcitrant compound in these fractions ${ }^{34}$.

Cellulose-degrading enzymes were playing an important role in decomposing soil microorganism, and the $c b h / g e n e$ were usually regard as a suitable marker for the cellulolytic fungi ${ }^{14}$. In this study, $c b h /$ gene were regarded as the fungal glycoside hydrolase family 7 from the Basidiomycota and Ascomycota ${ }^{10}$. Our results indicated that abundance of $c b h / g e n e$ in different particle-size fractions were changed under long-term fertilization condition, and the abundance of $c b h / g e n e$ were increased with application of crop residue and organic manure fertilizer (RF and OM treatments) (Fig. 2, Table 2), the reason maybe that there were more nutrient and $\mathrm{C}$ source with organic manure treatments, which was provide an appropriate soil environment, soil properties and nutrient for soil cellulolytic fungi multiplying. However, some results indicated that abundance of cellulolytic gene were decreased under long-term application of mineral fertilizer condition ${ }^{24}$. Furthermore, the $c b h /$ gene abundance were significantly related to the content of SOC and $\mathrm{C} / \mathrm{N}$ ratio ${ }^{15}$. The lowest $c b h /$ abundance and higher total $\mathrm{N}$ content were showed in 2-0.1 $\mu \mathrm{m}$ fraction, thus there were no significantly relationship between $c b h /$ abundance and total $\mathrm{N}$ content (Table 3). Soil $\beta$ cellobiohydrolase and $\beta$-glucosidase activities were significantly correlated with $c b h /$ gene abundance (Table 3), suggested that change in abundance of these cellulolytic fungi of functional relevance in terms of $\mathrm{C}$ transformation in paddy ecosystem, consistent with the results of the previous studies ${ }^{24,32}$.

Multicellular actinomycetes and fungi were usually regard as efficient cellulose decomposers, and actinobacteria was playing an important role in SOM turnover, breakdown of recalcitrant molecules such as cellulose ${ }^{35}$ and polycyclic aromatic hydrocarbons ${ }^{15}$. In the present study, the results showed that $\mathrm{GH} 48$ gene abundance in different particle-size fractions were significantly changed under long-term fertilization condition, was ten times lower than that of $c b h / g e n e$ abundance (Fig. 2, Fig. 3). The reason maybe that qPCR primers did not included all actinobacterial GH48 gene diversity from culture actinobacterial strains in the present experiment condition ${ }^{15}$. Therefore, the $\mathrm{GH} 48$ gene abundance in different particle-size fractions were lower than that of $c b h /$ gene abundance. Meanwhile, our results indicated that GH48 gene abundance were highest in 200-50 $\mu \mathrm{m}$ fraction and lower in 50-2 $\mu \mathrm{m}$ and 2-0.1 $\mu \mathrm{m}$ fractions, and there has significantly correlation between $\mathrm{GH} 48$ abundance with $\mathrm{SOC}$, total N contents, $\mathrm{C} / \mathrm{N}$ ratio and soil cellulase activity (Table 3 ). These results were revealed that high $\mathrm{C} / \mathrm{N}$ ratio had negative influence on soil extracellular hydrolytic enzymes during litter decomposition, and soil enzyme activity synthesized by cellulolytic microbes in particle-size fractions with lower soil $\mathrm{C} / \mathrm{N}$ ratio were increased with application of crop residue and organic manure practice, which were consistent with the results of previous studies 24,32 .

In recent years, some results indicated that soil humification process is an important index of the change in the amount and chemical structure of humus ${ }^{32,37}$. In the present study, the results showed that there was significantly 
relationship between cellulolytic microbial abundance with soil humus structural characteristic (Table 3). And the results also showed that HA were higher correlation with cellulolytic gene abundance, suggested that HA was more active and sensitive to environment change than that of FA ${ }^{38}$. Meanwhile, there was some different relationship between FA and HA with cellulolytic gene abundance (Table 4) for that naturally different characteristic of humus component ${ }^{39}$. In the previous study, the results indicated that o-alkyl $\mathrm{C}$ were generally considered as an easily biodecomposable organic component ${ }^{40}$. In this study, there was positively correlation between o-alkyl $\mathrm{C}$ of FA with cellulolytic gene abundance and the negatively relationship between alkyl/o-alkyl $C$ with cellulolytic gene abundance were confirmed that cellulose-degrading microbial community prefer the less humified fractions such as $200-50 \mu \mathrm{m}$ fraction, rather than smaller fraction especially 2-0.1 $\mu \mathrm{m}$ fraction that contained more stable and recalcitrant substrate (Table 3; Fig. 2 and 3). The aromatic C of FA and o-alkyl C of HA were no correlation with both cbh/ and GH48 gene

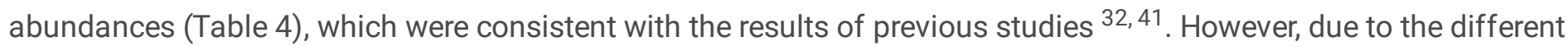
distribution of functional microbial group in soil particle-size fractions mediating soil $\mathrm{C}$ transformation by using culture-independent method, further analysis were still needed to investigate the situ expression of glucoside hydrolase gene in rhizosphere soil under long-term fertilization condition.

\section{Conclusion}

This result showed that distribution of humus component (FA, HA and HM) were changed under long-term application of fertilization condition, and the FA, HA and HM C contents in $>2000 \mu \mathrm{m}$ and $2000-50 \mu \mathrm{m}$ fractions were significantly improved with MF, RF and OM treatments. The results indicated that alkyl C and oalkyl C groups of FA in $>2000 \mu \mathrm{m}$ and 2000-50 $\mu \mathrm{m}$ fractions were higher than that of the other fractions, the order of relative abundance of different $\mathrm{C}$ groups of $\mathrm{HA}$ in different particle-size fractions were following alkyl $\mathrm{C}>0$-alkyl $\mathrm{C}>$ aromatic $\mathrm{C}>$ carboxylic $\mathrm{C}$. Compared without fertilizer input treatment, the abundance of $\mathrm{cbh} /$ and $\mathrm{GH} 48$ genes in different particle-size fractions were increased with chemical fertilizer, crop residue and organic manure with chemical fertilizer treatments (MF, RF and $\mathrm{OM}$ ). There has closely relationship between cellulolytic abundance with chemical composition of FA and HA, which indicated that cellulolytic microorganism were play an important role in maintaining and changing chemical composition of FA and HA. However, further studies were necessary to investigate the role of abundance of soil fungi and actinobacteria in soil carbon cycling related to long-term fertilizer management.

\section{Declarations}

\section{Acknowledgements}

This study was supported by National Natural Science Foundation of China (31872851), Innovative Research Groups of the Natural Science Foundation of Hunan Province (2019JJ10003).

The authors have declared no conflict of interest.

\section{Author Contribution}

Haiming Tang, Xiaoping Xiao and Chao Li wrote the main manuscript text, Yilan Xu and Kaikai Cheng prepared figures 1-3, and Weiyan Li, Kaikai Cheng prepared table 1-2, Lihong Shi and Li Wen prepared table 3-4. All authors reviewed the manuscript.

\section{References}


1. Smith, P., et al. REVIEW: the role of ecosystems and their management in regulating climate, and soil, water and air quality. Journal of Applied Ecology, 50, 812-829 (2013).

2. Lal, R. Soil carbon sequestration impacts on global climate change and food security. Science 304, 1623-1627 (2004).

3. Plaza-Bonilla, D., Álvaro-Fuentes, J., \&Cantero-Martínez, C. Identifying soil organic carbon fractions sensitive to agricultural management practices. Soil \& Tillage Research, 139, 19-22 (2014).

4. Joliveta, C., et al. Carbohydrate dynamics in particle-size fractions of sandy spodosols following forest conversion to maize cropping. Soil Biology and Biochemistry, 38, 2834-2842(2006).

5. Ling, N., et al. Response of the bacterial diversity and soil enzyme activity in particle-size fractions of Mollisol after different fertilization in a long-term experiment. Biology and Fertility of Soils, 50, 901-911(2014)..

6. Stevenson, F.J. Humic Chemistry: Genesis, Composition, Reactions, second ed. Wiley, New York. (1994).

7. Schǒning, I., \& Kǒgel-Knabner, I. Chemical composition of young and old carbon pools throughout Cambisol and Luvisol profiles under forests. Soil Biology and Biochemistry, 38, 2411-2424 (2006).

8. Reddy, S.B., et al. Soil humic and fulvic acid fractions under different land Use systems. Madras Agricultural Journal,99, 507-510(2012).

9. Jindo, K., et al. Influence of stability and origin of organic amendments on humification in semiarid soils. Soil Science Society of America Journal,75, 2178-2187(2011).

10. Stursová, M., et al. Cellulose utilization in forest litter and soil: identification of bacterial and fungal decomposers. FEMS Microbiology Ecology, 80, 735-746 (2012).

11. Kubicek, C.P., Seidl, V., \& Seiboth, B. Plant cell wall and chitin degradation. In: Borkovish, K.A., Ebbole, D.J. (Eds.), Cellulose and Molecular Biology of Filamentous Fungi. ASM Press, Washington, DC, USA, pp. 96-413. (2010)

12. Baldrian, P., \& Valásková, V. Degradation of cellulose by basidiomycetous fungi. FEMS Microbiology Ecology, 32, 501-521 (2008).

13. Edwards, I.P., Upchurch, R.A., \& Zak, D.R. Isolation of fungal cellobiohydrolase I genes from sporocarps and forest soils by PCR. Applied and Environmental Microbiology, 74, 3481-3489 (2008).

14. Weber, C.F., et al. Responses of soil cellulolytic fungal communities to elevated atmospheric $\mathrm{CO}_{2}$ are complex and variable across five ecosystems. Environmental Microbiology, 13, 2778-2793(2011).

15. de Menezes, A.B., et al. C/N Ratio Drives Soil actinobacterial cellobiohydrolase gene diversity. Applied and Environmental Microbiology, 81, 3016-3028(2015).

16. Yeh, Y.F., et al. A metagenomic approach for the identification and cloning of an endoglucanase from rice straw compost. Gene. 519, 360-366 (2013).

17. Yang, X.Y., et al. Effects of contrasting soil management regimes on total and labile soil organic carbon fractions in a loess soil in China. Geoderma. 177-178, 49-56(2012).

18. Tang, H.M., et al. Effects of long-term fertiliser regime on soil organic carbon and its labile fractions under double cropping rice system of southern China. Acta Agriculturae Scandinavica, Section B-Soil \& Plant Science, 70, 409418 (2020).

19. Tang, H.M., et al. Long-term effects of NPK fertilizers and organic manures on soil organic carbon and carbon management index under a double-cropping rice system in Southern China. Communications in Soil Science and Plant Analysis, 49, 1976-1989 (2018).

20. Stemmer, M., Gerzabek, M.H., \& Kandeler, E. Organic matter and enzyme activity in particle-size fractions of soils obtained after low-energy sonication. Soil Biology and Biochemistry, 30, 9-17 (1998). 
21. Zhang, Q., et al. Fatty-acid profiles and enzyme activities in soil particle-size fractions under long-term fertilization. Soil Science Society of America Journal, 80, 97-111(2016).

22. Pane, C., et al. Agricultural waste-based composts exhibiting suppressivity to diseases caused by the phytopathogenic soil-borne fungi Rhizoctonia solani and Sclerotinia minor. Applied Soil Ecology, 65, 43-51(2013).

23. Baldock, J.A., et al. Assessing the extent of decomposition of natural organic materials using solid state ${ }^{13} \mathrm{C}$ NMR spectroscopy. Australian Journal of Soil Research, 35, 1061-1083 (1997).

24. Fan, F., et al. Impacts of organic and inorganic fertilizers on nitrification in a cold climate soil are linked to the bacterial ammonia oxidizer community. Microbial Ecology, 62, 982-990 (2011).

25. SAS. SAS Software of the SAS System for Windows. SAS Institute Inc, Cary, NC, USA. (2008)

26. Senesi, N., \& Loffredo, E. The chemistry of soil organic matter. In: Sparks, D.L. (Ed.), Soil Physical Chemistry, second ed. CRC Press, Boca Raton, pp. 239-370. (1999)

27. Morales, J., et al. Degradation of carbofuran and carbofuran-derivatives in presence of humic substances under basic conditions. Chemosphere. 89, 1267-1271 (2012).

28. Lehtonen, K., H€anninen, K., \& Ketola, M. Structurally bound lipids in peat humic acids. Organic Geochemistry, 32, 33-43 (2001).

29. Güngǒr, E.B., \& Bekbǒlet, M. Zinc release by humic and fulvic acid as influenced by $\mathrm{pH}$, complexation and DOC sorption. Geoderma. 159, 131-138 (2010).

30. Abakumov, E., Lodygin, E., \& Tomashunas, V. ${ }^{13} \mathrm{C}$ NMR and ESR characterization of humic substances isolated from soils of two Siberian Arctic islands. International Journal of Ecology, 3, 1-7 (2015).

31. Rosenberg, W., et al. Liming effects on the chemical composition of the organic surface layer of a mature Norway spruce stand (Picea abies L.] Karst.). Soil Biology and Biochemistry, 35, 155-165 (2003).

32. Zhang, Q., et al. Evident variations of fungal and actinobacterial cellulolytic communities associated with different humified particle-size fractions in a long-term fertilizer experiment. Soil Biology and Biochemistry, 113, 1-13 (2017).

33. Yang Z, Singh B, Sitaula B. Soil organic carbon fractions under different land uses in Mardi watershed of Nepal. Communications in Soil Science and Plant Analysis, 35: 615-629 (2004).

34. Anderson, D.W., \& Paul, E.A. Organo-mineral complexes and their study by radiocarbon dating. Soil Science Society of America Journal, 48, 298-301 (1984).

35. McCarthy, A.J. Lignocellulose-degrading actinomycetes. FEMS Microbiology Reviews, 46, 145-163 (1987).

36. Leitner, S., et al. Influence of litter chemistry and stoichiometry on glucan depolymerization during decomposition of beech (Fagus sylvatica L.) litter. Soil Biology and Biochemistry, 50, 174-187 (2012)..

37. Ikeya, K., Yamamoto, S., \& Watanabe, A. Semiquantitative GC/MS analysis of thermochemolysis products of soil humic acids with various degrees of humification. Organic Geochemistry, 35, 583-594 (2004).

38. Shindo, H., et al. d13C values of organic constituents and possible source of humic substances in Japanese volcanic ash soils. Soil Science 170, 175-182 (2005).

39. Li, C.L., et al. Moisture effect on soil humus characteristics in a laboratory incubation experiment. Soil and Water Research, 11, 37-43 (2016).

40. Preston, C.M., \& Trofymow, J.A. Variability in litter quality and its relationship to litter decay in Canadian forests. Canadian Journal of Botany, 78, 1269-1287 (2000).

41. Chavez-Vergara, B., et al. Organic matter dynamics and microbial activity during decomposition of forest floor under two native neotropical oak species in a temperate deciduous forest in Mexico. Geoderma. 235-236, 133-145 (2014).

Page $12 / 14$ 

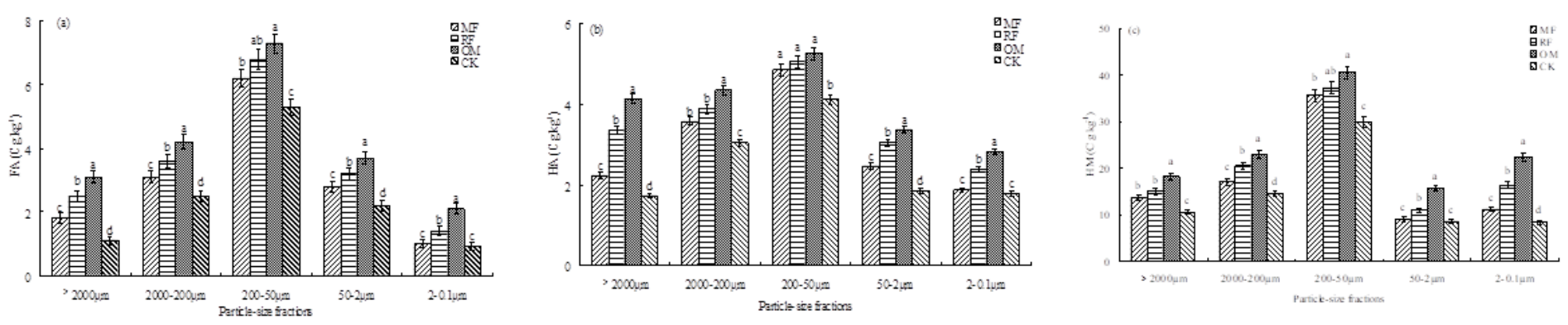

Figure 1

Fulvic acid (FA), humic acid (HA) and humin (HM) contents from different particle-size fractions with different fertilizer treatments MF: chemical fertilizer alone; RF: rice straw residue and chemical fertilizer; OM: 30\% organic manure and $70 \%$ chemical fertilizer; CK: without fertilizer input as control. (a) fulvic acid (FA), (b) humic acid (HA), (c) humin (HM). Different lowercase letters indicated significant differences $(p<0.05)$ among different fertilizer treatments. Error bars represent standard error of the mean $(n=3)$.

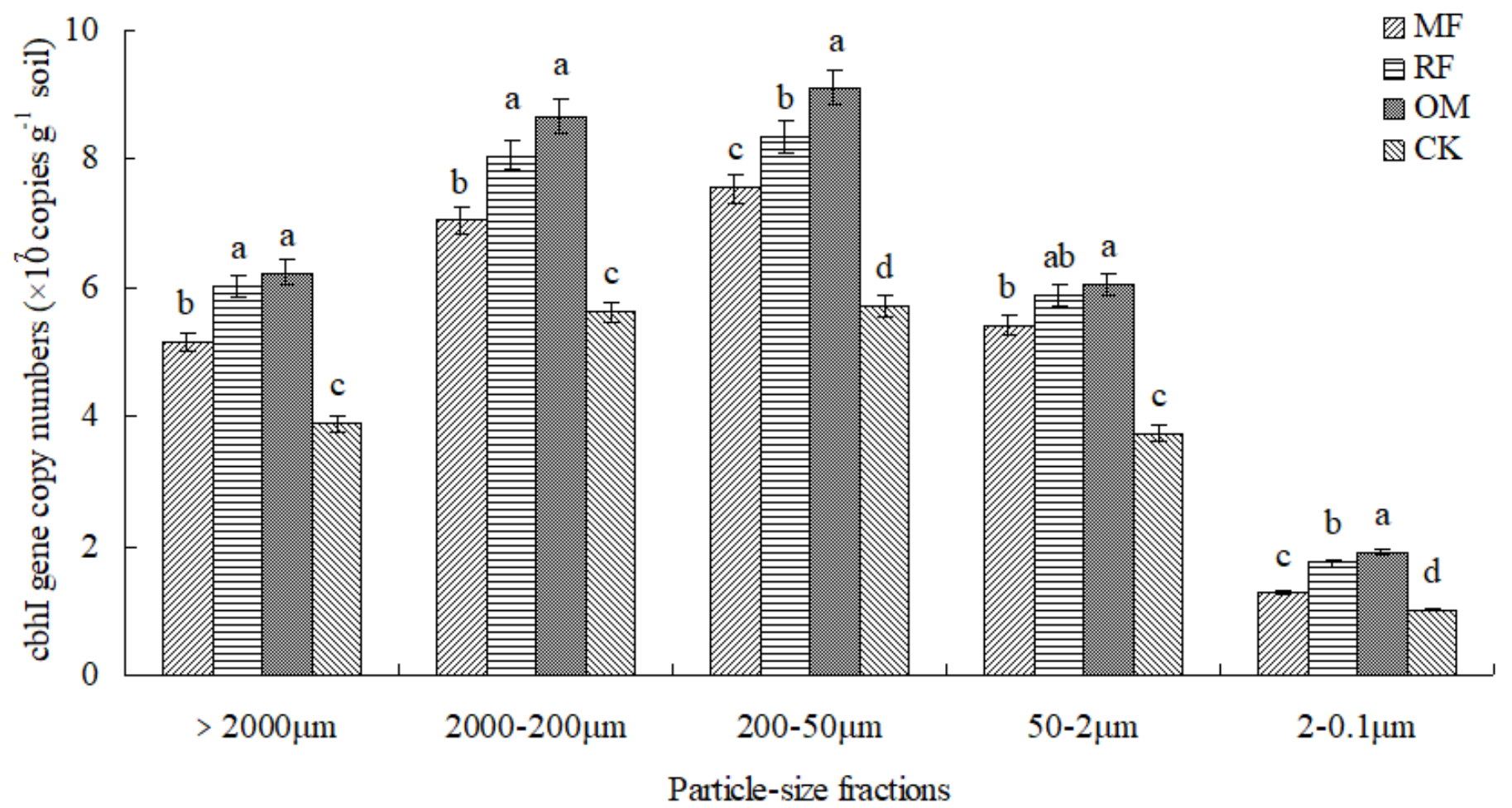

Figure 2

cbhl gene copy numbers in different particle-size fractions with long-term fertilizer treatments MF: chemical fertilizer alone; RF: rice straw residue and chemical fertilizer; OM: $30 \%$ organic manure and $70 \%$ chemical fertilizer; CK: without fertilizer input as control. Different lowercase letters indicated significant differences $(p<0.05)$ among different fertilizer treatments. Error bars represent standard error of the mean $(n=3)$. 


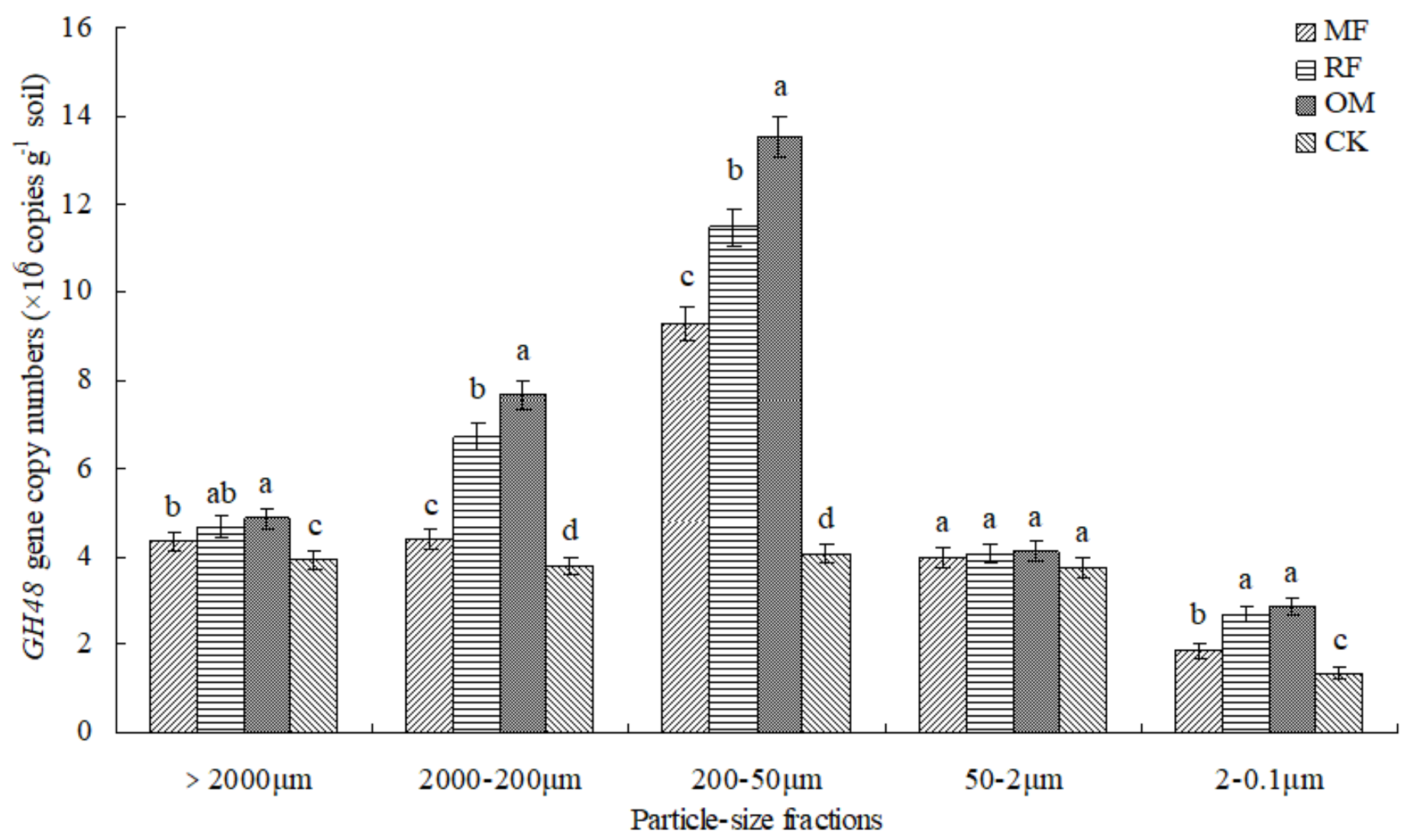

Figure 3

GH48 gene copy numbers in different particle-size fractions with long-term fertilizer treatments MF: chemical fertilizer alone; RF: rice straw residue and chemical fertilizer; OM: 30\% organic manure and 70\% chemical fertilizer; CK: without fertilizer input as control. Different lowercase letters indicated significant differences $(p<0.05)$ among different fertilizer treatments. Error bars represent standard error of the mean $(n=3)$. 